\begin{tabular}{c} 
Volume and Issues Obtainable at Center for Sustainability Research and Consultancy \\
Journal of Business and Social Review in Emerging Economies \\
ISSN: 2519-089X (E): 2519-0326 \\
Volume 1: Issue 1 June 2017 \\
CSRᄃ \\
Journal homepage: $\underline{\text { www.publishing.globalcsrc.org/jbsee }}$ \\
\hline
\end{tabular}

\title{
Role of Entrepreneurial Orientation in Talent Retention among Malaysian Engineers
}

\author{
${ }^{1}$ Idris Osman, ${ }^{2}$ Fauziah Noordin, ${ }^{3}$ Idaya HusnaMohd, ${ }^{4}$ Koe Wei Loon \\ ${ }^{1}$ Faculty of Business and Management, UniversitiTeknologi MARA (UiTM), Shah Alam, Selangor, \\ Malaysiaidrisphd2015@gmail.com \\ ${ }^{2}$ Faculty of Business and Management, UniversitiTeknologi MARA (UiTM), Shah Alam, Selangor, \\ Malaysiafauziah716@salam.uitm.edu.my \\ ${ }^{3}$ Faculty of Business and Management, UniversitiTeknologi MARA (UiTM), Shah Alam, Selangor, \\ Malaysiaidayahusna@salam.uitm.edu.my \\ ${ }^{4}$ Faculty of Business and Management, UniversitiTeknologi MARA (UiTM), City Campus, Melaka, \\ Malaysiakoeweiloon@yahoo.com
}

\section{ARTICLEDETAILS}

\section{History}

Revised format: Nov 2017

AvailableOnline: Dec 2017

\section{Keywords \\ Engineers \\ Entrepreneurial orientations \\ Intention to stay \\ Retention \\ Talent \\ Malaysia}

JEL Classification:

L26, L29

\begin{abstract}
Purpose:This paper examines the linkage between entrepreneurial orientation (EO) and talent retention amongst Malaysian engineers from the perspective of entrepreneurial orientation theory.

Design/Methodology/Approach:A cross-sectional survey of 104 engineers from private organisations in Malaysia was conducted to test the hypothesised relationships between constructs. The population comprised graduate and professional engineers who were registered under the Board of Engineers Malaysia (BEM). The purposive sampling method was employed for data analysis purposes. Data was analysed using partial least square-structural equation modelling technique.

Findings:The results of this study indicated a significant relationship between innovativeness, proactiveness, risk-taking, and competitive aggressiveness and the intention to stay (ITS). Autonomy was found not significant in predicting engineers' ITS the same jobs. Engineers require EO to support their freedom of ideas and thoughts to exploit opportunities, produce creativity, and solve engineering task-related problems and uncertainty situations.

Implications/Originality/Value:EO dimensions can be used to predict engineers' ITS current employments. This study provides crucial information for the organisations and policy makers to develop mechanisms and policies to enhance the engineers' involvement of effective EO for increasing retention behaviours and career satisfaction. As the EO of engineers' increase, the ITS will also increase.
\end{abstract}

(C) 2017 The authors, under a Creative Commons AttributionNonCommercial 4.0

Corresponding author's email address: idrisphd2015@gmail.com

Recommended citation:Osman. I., Noordin.F.,Husna.I. andWei.K. The Role of Entrepreneurial Orientation in Talent Retention amongst Malaysian Engineers.Journal of Business and Social Review in Emerging Economies, 3(2),157-168.DOI:https://doi.org/10.26710/jbsee.v3i2.189

\section{Introduction}

Over thirty years ago, studies relating to behaviours, attitudes, and traits had become a central issue underlying engineers' complex behavioural intentions, career orientations, and employee shortages in the 
engineering sector (Abdull Rahman, 2012; Igbaria, \& Siegel, 1992;Igbaria, Kassicieh, \& Silver, 1999; Kharbanda, \&Stallworthy, 1990; Williamson, Lounsbury, \& Han, 2013). Attention was given to engineers' perceiving their engineering paths to be meaningful career experiences, and how core entrepreneurial orientation (EO) components influenced their career expectations, job performance, and job satisfaction. Engineering requirements are created and used to determine engineers' career orientations on greater work values for engineers (Alavi, Moteabbed, \&Arasti, 2012). Evidence suggests that engineers' EO are a crucial component for the entrepreneurial process, successful entrepreneurial organisations and decisions to remain for the one's job tenure (Menzel, Aaltio, \&Ulijn, 2007; Tremblay, Wils, \&Proulx, 2002; Yang, Ma, \& Hu, 2011).

It is believed that the use of EO is likely to resolve the quitting behaviours of engineers to move to another job. If an organisation knows how to control the engineers' EO within an organisation, low job performance, and turnover behaviours can be avoided (Lee, 1994). In the literature, organisations employed EO for measuring performance, growth, and productivity (Antoncic, \&Antoncic, 2011; Entebang, Harrison, \& Run, 2010;Jia, Wang, Yu, 2014). However, Kollman, Christofor, and Kuckertz (2007) argued that a successful entrepreneurial organisation gains from an individual's participation in EO processes and activities. The impact of technology, too, has strongly influenced organisations to consider certain types of individual behaviours and attitudes for successful EO (Grip \& Smits, 2012; Menzel, et al., 2007; Oyedele, 2010).

Critical questions have vigorously challenged many scholars to overlook adapting EO within an organisational area to predict intention to stay (ITS) amongst engineers. Previous conceptual study, qualitative and empirical research has clearly acknowledged the research gaps between the influences of EO and individuals' entrepreneurial intentions and job performance (Bolton \& Lane, 2012; Elenurm, 2012; Kollman et al., 2007; Wu, 2009). From a theoretical gap, the EO theory has not clearly defined and expended the use of EO for predicting individual behavioural intentions. Despite the importance of managing engineers' behaviours and attitudes, no attention has been paid to the role of EO from an individual analysis in predicting engineers' ITS. Hence, this study has been aimed at investigating the influence of EO (e.g., innovativeness, proactiveness, risk-taking, autonomy, and competitive aggressiveness) on ITS amongst Malaysian engineers in private organisations.

\section{Literature Review}

Talent can be defined as a person who has high skills, knowledge, and expertise in producing and innovating ideas (Festing\&Scha“fer, 2014). He or she can be an excellent performer and a valuable asset to help organisations lead with core competencies. From an organisational level, talent retention is one of the crucial talent management activities and it has received a critical attention to retain talents (Gelens, Dries, Hofmans, \&Pepermans, 2013; Lewis \& Heckman, 2006; Zhang \& Bright, 2012). Talent retention is defined as a process of encouraging talented individuals to remain with the same employment.

\subsection{Intention to Stay}

Intention to stay (ITS) refers to an employee's consciousness and willingness to stay in the same job and organisation on a long-term basis (Tett\& Meyer, 1993). It has been considered as the best predictor of the actual turnover behaviour of an employee. Research has consistently shown that ITS lacks usage in predicting positive behavioural intentions. Throughout this study, the term ITS will refer to an engineer's willingness to stay with his or her current employment.

\subsection{The Relationships between EO and ITS}

EO theory relates to an organisation's strategic orientation which concerns entrepreneurial aspects, such as decision-making styles, processes, practices, and methods (Lumpkin \&Dess, 1996). Risk-taking, innovativeness, and proactiveness are the main features, and each feature is linked to an organisation's willingness to take high risk projects, be bold and aggressive in exploiting opportunities, and initiate 
actions to which competitors respond (Covin\&Slevin, 1986; Lumpkin et al., 1996).

\subsubsection{Innovativeness and ITS}

Innovativeness is defined as willingness to support creativity, experimentation, and creative activities in producing new products, services, and new technology (Lumpkin et al., 1996). From an individual's perspective, innovative behaviours pursue an individual's ability to explore new opportunities, creatively (Bolton et al., 2012). Bolton et al. (2012) revealed that 1,102 students' innovativeness behaviours were positively correlated with entrepreneurial propensity at $0.36^{* *}$. There is some evidence that innovativeness directly influences retention outcomes on individual employees. Moreover, engineers need the freedom to be creative and original, and permanently involved in any innovation and changes within organisations (Alavi et al., 2012; Igbaria et al., 1992; Kharbanda et al., 1990; Menzel et al., 2007; Williamson et al., 2013). Thus, the following hypothesis is proposed:

H1: Innovativeness is positively related to engineers' ITS.

\subsubsection{Proactiveness and ITS}

As Lumpkin et al. (1996) states: "proactiveness refers to an opportunity seeking, forward-looking perspective which involves the introduction of new products or services ahead of competition and acting in anticipation of future demand". Proactive behaviours capture the engineers' creativity in solving routine and non-routine engineering-related problems (Campbell, Gluesing, \&Perelli, 2012;Menzel et al., 2007; Williamson et al., 2013). Proactiveness enhances the engineers' ability to think conceptually. Difficulties arise when modern organisations are not engaged with proactive behaviours, as a result, the effective individual's turnover cannot be affected (Crant, 2000). The higher the proactive behaviours of individuals (e.g., engineers), the less likely it is that engineers will leave their current employment. Hence, we propose that:

H2: Proactiveness will positively relate to the engineers' ITS.

\subsubsection{Risk-taking and ITS}

Risk-taking refers to a tendency to take bold actions into unknown new markets, committing a large portion of resources to ventures with uncertain outcomes (Lumpkin et al., 1996). Risk-taking behaviour assumes individual risks and willingness to make commitments (Bolton et al., 2012). A consequence of implementing risk-taking behaviour is shaping the engineers' ability to predict uncertain situations and task-related problems that can lead to a higher satisfaction and ITS (Igbaria et al., 1992). Despite this, engineers tend to solve daily technical problems using their conscious and sub-conscious mental systems to create interesting and enjoyable environments (Campbell et al., 2012; and Kharbanda et al., 1990). Assigning interesting tasks have positively influenced the engineers' job involvement and career satisfaction $(r=0.32, p<0.01)$, and has been negatively correlated to the intention to leave $(r=-0.30$, $p<0.01$ ) (Igbaria et al., 1992). Hence, based on the literature, it is hypothesised that:

H3: A higher level of risk-taking by engineers will lead to higher ITS.

\subsubsection{Autonomy and ITS}

Autonomy refers to the independent action of an individual or a team bringing forth the idea or vision and carrying it through to competition (Lumpkin et al., 1996). Khalili, Nejadhussein andFazel(2013) believe that a significant amount of autonomy affects an individual's goal achievement and the challenging nature of the job; as all these motivational factors lead to a higher level of job satisfaction. For Bolton et al. (2012) autonomy, however, has failed to predict an individual's entrepreneurial intention due to lower consistency (0.208). Participation by engineers in any decision-making process will make them recognise potential problems and solutions to the related engineering-tasks. Autonomy is the core of the engineers' career preferences (Tremblay et al., 2002). Autonomy exerts a powerful effect on ITS through improving the EO within an organisation. Based on these arguments, it is hypothesised that:

H4: Autonomy has a positive and significant relationship with engineers' ITS 


\subsubsection{Competitive Aggressiveness and ITS}

Competitive aggressiveness is a necessary element to lead in performance over competitors (Lumpkin et al., 1996). Organisations with a lower competitive aggressiveness would be limited with the innovation process. The important implication of the competitive aggressiveness definition has leveraged more attempts from scholars to relate to organisational performance, growth, and productivity. From an individual's effectiveness (e.g., job performance and satisfaction), competitive aggressiveness is used for predicting individual (e.g., student) entrepreneurial intentions (Bolton et al., 2012; Elenurm, 2012; Zhang et al., 2012). However, competitive aggressiveness behaviour failed to predict individual entrepreneurial intentions (Bolton et al., 2012). Much uncertainty, however, still exists about the effect of competitive aggressiveness and its influence on ITS amongst engineers. In view of this, the next proposed hypothesis is:

\section{H5: Competitive aggressiveness is positively and significantly related to ITS amongst engineers.}

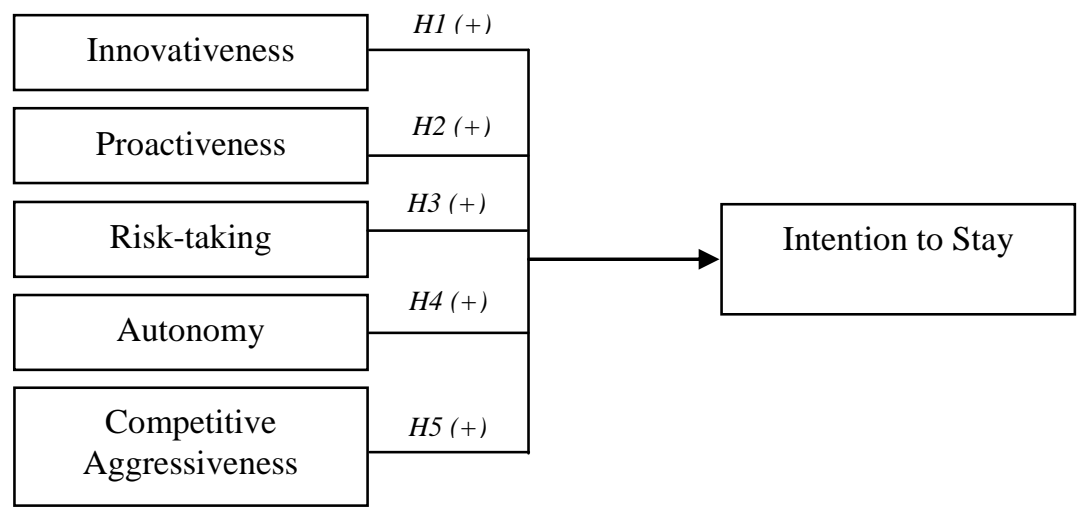

Figure 1. Research Model

\section{Methodology}

\subsection{Samples and Research Procedures}

An exploratory study was designed to answer the primary objective to examine the influence of entrepreneurship on talent retention amongst engineers. The population for this study was the engineers who had registered with the Board of Engineers Malaysia (BEM). Confidentiality was ensured to the respondents and the organisations. The selection of the samples was on the basis of the purposive sampling method, and the responses obtained were subjected to a quantitative analysis. A total of 112 responses were obtained from 300 questionnaires. From the 112, 8 were discarded and only 104 were considered for analysis. This yielded a response rate of 34.67 percent.

\subsection{Measures and Instruments}

The scale used to measure the items was rated on a 7-point Likert response scale ranging from 1 (strongly disagree) to 7 (strongly agree). The scales for measuring the five dimensions of entrepreneurship were derived from the EO theory. This scale consisted of innovativeness (seven items), proactiveness (seven items), risk-taking (six items), autonomy (four items), and competitive aggressiveness (five items). All items used were on the seven-item scale developed from previous studies (Covin et al., 1986; Lumpkin et al., 1996). Six items were used from the scale developed by Govaerts, Kyndt, Dochy, andBaert(2011) to measure the ITS.

\subsection{Data Analysis Procedure}

The data were analysed using SmartPLS 3.2.6, a variance-based structural equation modelling (SEM) to test the hypotheses of the study (Hair, Hult, Ringle, \&Sarstedt, 2014). The reasons for adopting SmartPLS were: a) capable to handle reflective and formative measures; b) able to accommodate the small sample size; and c) to predict the relationships between variables. Itcan alsosimultaneously testing the two models: a) measurement; and b) structural model. 


\section{Results}

From a total of 104,85 participants (81.7 percent) were graduate engineers (81.7 percent) whilst 19 (18.3 percent) represented professional engineers. The total sample was comprised of 85 males $(81.7$ percent) and 19 females (18.3 percent), 55.8 percent of the participants were aged between 26 and 35 years old, 57 (54.8) percent were married, and the majority of the participants were Malays (82 percent). The majority of the participants or 83 (79.8 percent) had a graduate degree, 60 participants (43.3 percent) were working in Melaka and 45 (43.3 percent) of the participants had between 1 to 5 years' experience. Manufacturing firms were the highest (38.5 percent) contribution for this study. Table 3 presents the demographic profile.

Table 3.Demographic Profile

\begin{tabular}{|c|c|c|}
\hline Category & Frequency & Percentage \\
\hline \multicolumn{3}{|l|}{ Status of Designation } \\
\hline Graduate Engineers & 85 & 81.7 \\
\hline Professional Engineers & 19 & 18.3 \\
\hline \multicolumn{3}{|l|}{ Gender } \\
\hline Male & 85 & 81.7 \\
\hline Female & 19 & 18.3 \\
\hline \multicolumn{3}{|l|}{ Age } \\
\hline Below 25 years olds & 9 & 8.7 \\
\hline 26-35 years old & 58 & 55.8 \\
\hline $36-45$ years old & 26 & 25.0 \\
\hline 46-55 years old & 9 & 8.7 \\
\hline 56 years old and more & 2 & 1.9 \\
\hline \multicolumn{3}{|l|}{ Marital Status } \\
\hline Single & 46 & 44.2 \\
\hline Married & 57 & 54.8 \\
\hline Divorced & 1 & 1.0 \\
\hline \multicolumn{3}{|l|}{ Race } \\
\hline Malay & 82 & 78.8 \\
\hline Chinese & 17 & 16.3 \\
\hline Indian & 5 & 4.8 \\
\hline \multicolumn{3}{|l|}{ Education Level } \\
\hline Diploma & 16 & 15.4 \\
\hline Bachelor Degree & 83 & 79.8 \\
\hline Master Degree & 4 & 3.8 \\
\hline $\mathrm{PhD}$ & 1 & 1.0 \\
\hline \multicolumn{3}{|l|}{ Length of Service } \\
\hline $1-5$ years & 45 & 43.3 \\
\hline $6-10$ years & 25 & 24.0 \\
\hline $11-15$ years & 21 & 20.0 \\
\hline 16 years and more & 13 & 12.5 \\
\hline \multicolumn{3}{|l|}{ Location } \\
\hline Johor & 19 & 18.3 \\
\hline Kuala Lumpur & 4 & 3.8 \\
\hline Melaka & 60 & 57.7 \\
\hline Selangor & 21 & 20.2 \\
\hline \multicolumn{3}{|l|}{ Specification of Business } \\
\hline Accounting/Finance/Banking & 1 & 1.0 \\
\hline Arts/Media/Communication & 1 & 1.0 \\
\hline Building/Construction & 14 & 13.5 \\
\hline Computer/IT & 2 & 1.9 \\
\hline Electrical \& Electronics & 13 & 12.5 \\
\hline Manufacturing & 40 & 38.5 \\
\hline Oil \& Gas & 24 & 23.1 \\
\hline Sciences & 1 & 1.0 \\
\hline Others & 8 & 7.7 \\
\hline
\end{tabular}




\subsection{The Measurement Model}

First, we assessed internal consistency (Composite Reliability), indicator reliability, convergent validity (AVE), discriminant validity (HTMT) and multicollinearity assessment. As reported in Table 4, factor loadings of each item exceeded 0.70 , ranged between 0.712 and 0.935 . It means the items used for measuring the constructs have satisfactory internal consistency reliability. For indicator reliability, items with loadings below 0.70 were removed and the items were INNO1, INNO6, RISK3, AUTO3, COMPI and COMP5. Composite reliability for each construct was ranged between 0.878 and 0.939 , and these threshold values were above 0.70. For the AVE, the values exceeded 0.50, ranged between 0.629 and 0.755 .

Next, we assessed the discriminant validity of the scales based on HTMT, as a new approach to assess the discriminant validity for variance-based SEM. These results indicated that the present study has adequate convergent validity since the value lower than 0.85 . Table 5 presents the correlation estimates for the HTMT. The results show that the correlations between constructs were ranged between 0.611 and 0.802 , and it was indicated that the discriminant validity was met the criteria for the HTMT assessment. For the multicollinearity assessment, the value of the Variance Inflation Factor (VIF) must be below than 0.50. Table 4 shows the VIF results that the mean values for each construct were ranged between 2.243 and 3.655. Therefore, the values of VIF posited that each of the independent variables (innovativeness, proactiveness, risk-taking, autonomy, and competitive aggressiveness) did not have a multicollinearity with its dependent variable (ITS).

Table 4. Assessment results of the measurement model

\begin{tabular}{|c|c|c|c|c|}
\hline Constructs/Items & Loadings & $\mathbf{C R}$ & AVE & VIF \\
\hline Innovativeness (INNO) & & 0.939 & 0.755 & 3.655 \\
\hline INNO2 & 0.815 & & & \\
\hline INNO3 & 0.876 & & & \\
\hline INNO4 & 0.935 & & & \\
\hline INNO5 & 0.864 & & & \\
\hline INNO7 & 0.852 & & & \\
\hline Proactiveness (PROAC) & & 0.935 & 0.673 & 3.321 \\
\hline PROACl & 0.843 & & & \\
\hline$P R O A C 2$ & 0.799 & & & \\
\hline PROAC 3 & 0.831 & & & \\
\hline PROAC4 & 0.712 & & & \\
\hline PROAC5 & 0.825 & & & \\
\hline PROAC6 & 0.870 & & & \\
\hline PROAC7 & 0.852 & & & \\
\hline Risk-taking (RISK) & & 0.900 & 0.644 & 2.647 \\
\hline RISKI & 0.749 & & & \\
\hline RISK2 & 0.773 & & & \\
\hline RISK4 & 0.768 & & & \\
\hline RISK5 & 0.859 & & & \\
\hline RISK6 & 0.857 & & & \\
\hline Autonomy (AUTO) & & 0.879 & 0.708 & 2.243 \\
\hline AUTO1 & 0.824 & & & \\
\hline AUTO2 & 0.864 & & & \\
\hline AUTO4 & 0.836 & & & \\
\hline Competitive Aggressiveness(COMP) & & 0.878 & 0.706 & 2.621 \\
\hline СОМР2 & 0.784 & & & \\
\hline СОМР3 & 0.846 & & & \\
\hline COMP4 & 0.888 & & & \\
\hline Intention to Stay (ITS) & & 0.894 & 0.629 & - \\
\hline ITS1 & 0.804 & & & \\
\hline ITS2 & 0.716 & & & \\
\hline ITS3 & 0.877 & & & \\
\hline ITS4 & 0.808 & & & \\
\hline ITS6 & 0.751 & & & \\
\hline
\end{tabular}


Table 5. Discriminant Validity (HTMT)

\begin{tabular}{lcccccc}
\hline Latent Constructs & AUTO & COMP & INNO & ITS & PROAC & RISK \\
\hline AUTO & & & & & & \\
COMP & $\mathbf{0 . 8 0 2}$ & & & & & \\
INNO & 0.762 & $\mathbf{0 . 6 9 8}$ & & & & \\
ITS & 0.610 & 0.461 & $\mathbf{0 . 6 9 8}$ & & \\
PROAC & 0.746 & 0.692 & 0.893 & $\mathbf{0 . 6 4 5}$ & \\
RISK & 0.757 & 0.890 & 0.688 & 0.609 & $\mathbf{0 . 6 1 1}$ & \\
\hline
\end{tabular}

Note: AUTO-Autonomy; COMP-Competitive Aggressiveness; INNO-Innovativeness; ITS-Intention to Stay; PROAC-Proactiveness; RISK-Risk-taking

\subsection{The Structural Model}

A structural model of PLS was examined each of the hypothesis to test the relationship between constructs that operationalised as latent variables (LVs). We performed the bootstrapping with a resampling 5000 for 104 cases to obtain the path estimates, standard errors and the $t$-statistics to report the significant relationships between variables. To evaluate the structural models' explanatory power, we calculated the $R^{2}$, the amount of variance explained by the exogenous variable (ITQ), whilst predictive power, we assessed path coefficient $(\beta)$, predictive relevance $\left(Q^{2}\right)$ and relative impact $\left(\mathrm{q}^{2}\right)$.

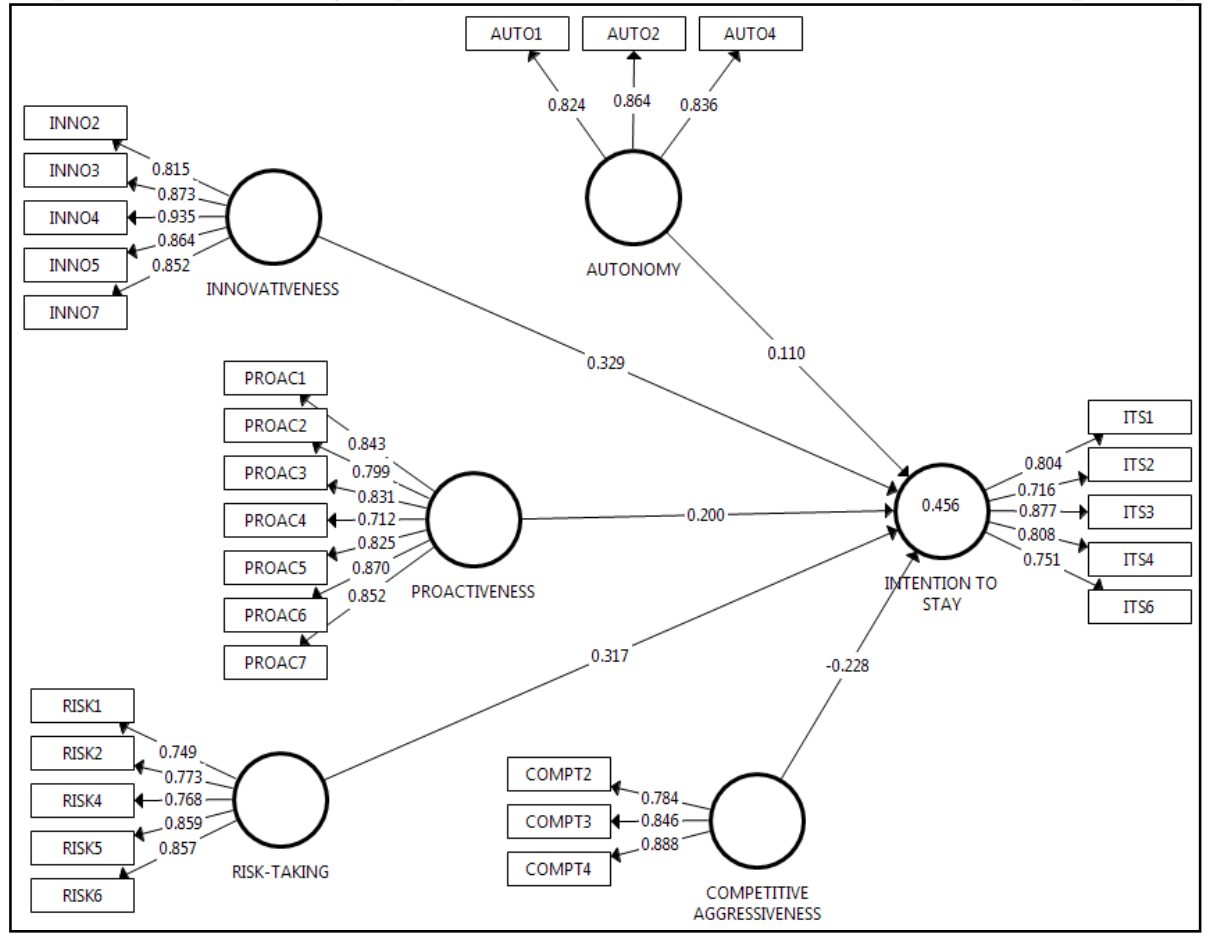

Figure 2: The PLS-Algorithm Results

For explanatory power, the LVs (e.g. innovativeness, proactiveness, risk-taking, autonomy, and competitive aggressiveness) were explained 45.6 percent of the variance, with $R^{2}(0.456)$. Next, we measured the effect size $\left(f^{2}\right)$ to witness the impact of the exogenous latent variables for the endogenous latent variables. The formula used for calculating the effect size was $\left(f^{2}=R^{2}\right.$ included- $R^{2}$ excluded / 1- $R^{2}$ included). The guidelines of the effect size were as follows: 0.35-large; 0.15-medium; and 0.02-small (Hair, Hult, Ringle, \& Sarsted, 2014). From the path model, the effect size of risk-taking $\left(f^{2}=0.061\right)$, innovativeness $\left(f^{2}=0.045\right)$, competitive aggressiveness $\left(f^{2}=0.021\right)$ and proactiveness $\left(f^{2}=0.020\right)$ were found to have small effect size on ITS. However, autonomy $\left(f^{2}=0.007\right)$ did not provide at least a small effect size on ITS.

Table 6 presents mixed results the path coefficients, observed t-statistics and the significance level of the hypothesized relationships between variables. From the analysis, it was found that innovativeness $(\beta=0.329 ; t=2.222, p<0.05)$ was positively related to ITS. Therefore, hypothesis $H 1$ was supported. 
Similarly, $H 2(\beta=0.200 ; t=1.688, p<0.05), H 3(\beta=0.317 ; t=2.479, p<0.05)$ and $H 5(\beta=-0.228 ; t=1.851$, $p<0.05)$ reported that proactiveness, risk-taking and competitive aggressiveness had a positive and significant relationships on engineers' ITS, therefore these three hypotheses were accepted. However, H4 has to be rejected as the data did not support the influence of autonomy on ITS amongst engineers $(\beta=0.110 ; t=0.959)$. The predictive relevance of the Stone-Geisser's $\left(Q^{2}\right)$ test of ITS was obtained by the blindfolding procedure, and the value was 0.421 , and it indicated that the predictive relevance of the PLS path model. Figure 3 shows the bootstrapping results.

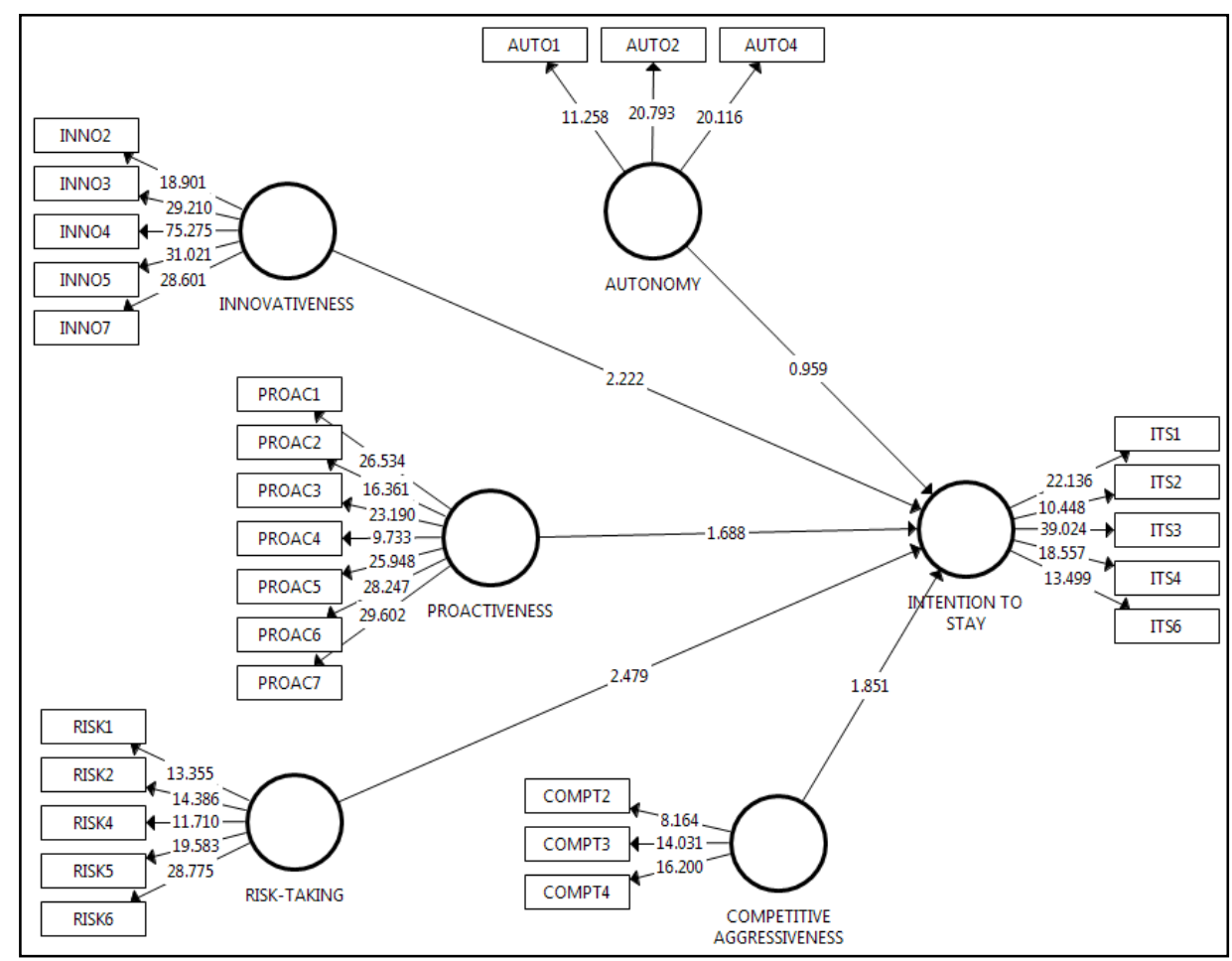

Figure 2: The PLS-Bootstrapping Results

Table 6: Results of path coefficients and observed t-statistics

\begin{tabular}{clccc}
\hline Hypotheses & \multicolumn{1}{c}{ Relationships } & Path Coefficient & t-value & Results \\
\hline$H 1$ & Innovativeness $\rightarrow$ ITS & 0.329 & $2.222^{*}$ & Supported \\
$H 2$ & Proactiveness $\rightarrow$ ITS & 0.200 & $1.688^{*}$ & Supported \\
$H 3$ & Risk-taking $\rightarrow$ ITS & 0.317 & $2.479^{*}$ & Supported \\
$H 4$ & Autonomy $\rightarrow$ ITS & 0.110 & 0.959 & Not Supported \\
$H 5$ & Competitive Aggressiveness $\rightarrow$ ITS & -0.228 & $1.851^{*}$ & Supported \\
\hline
\end{tabular}

Note: $* p<0.05$

\section{Discussion and Conclusion}

The present study was designed to fill the gaps of EO literature and its influence on talent retention amongst engineers in Malaysia. Malaysian engineers' positive behavioural intentions (e.g., ITS) depend on their EO. The positive relationships between EO (e.g., innovativeness, proactiveness, risk-taking, and competitive aggressiveness) and ITS have proved the arguments from previous studies (for example, Abdull Rahman, 2012; Bolton et al., 2012; Kollman et al., 2007; Igbaria et al., 1992). This current study concludes that engineers' ITS could be enhanced by practising EO within an organisation. As the EO of an engineer increases, it is probable that his or her ITS will also increase. Engineers with higher innovative behaviours will support exceptional ideas and novelty, and transform them into profitable products.

Autonomy and ITS, unfortunately, had no significant relationship. This present study believes that a considerable amount of autonomy will boost engineers' independent behaviours to resolve engineering task-related problems. From an individual's perspective, EO should strive for a high degree of autonomy, 
emphasising the individual's attitude towards innovation and involving the amount of risk to produce challenges and interesting tasks. Bigliardi, Petroni, and Dormio (2005); Igbaria et al. (1992) and Kharbanda et al. (1990) have seen engineers' behaviours as unique, unpredictable, and full of challenge. Whole phases of the engineer's life cycle within an organisation will be determined by several aspects, such as personality, socialisation, technical investment, learning and development, and career orientations (Abdull Rahman, 2012; Korte\& Li, 2015; Williamson et al., 2013).

The results supply crucial information to organisations as a fundamental means to understand engineers' behaviours and attitudes towards employment. The empirical results have revealed that EO support engineers' intention to remain in their current jobs and organisations. Although previous studies have confirmed that EO influence organisational performance (e.g., profit) and growth, none of the available literature provides a link between EBs and talent retention amongst engineers. The pure behaviours of engineers generally relate to a freedom to innovate things, facing uncertain situations, and exposing their creativity to technical knowledge. EO will emphasise the engineers' ability to overcome task-related challenges and act parallel to industrial demands. Moreover, with the emergence of technological, product, and administrative innovation, it has been claimed that many organisations must support the engineers' readiness to adopt ideas, and recognise and balance risks. Technology, for example, has been a crucial player in the competitive marketplace, and has influenced engineers' awareness about filling in the gaps of having core engineering skills and competencies to support their employment and behavioural expectations.

\section{Implications and Recommendations}

To date, organisations suffer from investing internal cost for recruiting and selecting new talented engineers to replace those who have left, and most probably the new staff may not have acquired the same talents. Cases of engineer migration to other firms have exposed firms to a higher turnover, and employers depend highly on their current experts. The dramatic increase in the need of engineers is linked to technological demands, superior technical knowledge, and the major roles in innovation processes (Campbell et al., 2012; Kharbanda et al., 1990). The awareness to attach EO in engineering tasks and jobs must be developed at the first place where engineers can use EO as a job performance reference. Therefore, it is advisable to make it a policy for the management and HR managers to link the engineers' level of performance with their EO for their career orientations. This will probably encourage engineering practitioners to design their jobs according to the engineers' abilities to develop and innovate ideas and thoughts, and transform them into tangible results.

A robust theoretical implication from previous studies (for example, Bolton et al., 2012; Kollman et al., 2007) mentioned that the EO theory is a valid construct for measuring an individual's entrepreneurial behaviour within an organisation. This argument is significant on why many individual employees rely on their EO for extending their commitment and retention decisions toward the same employment. The effort to match engineers with EO is said to develop engineers as potential entrepreneurs with several characteristics. Amongst them are autonomy, flexibility, adaptability and the capacity to cope with and manage change, self-motivation and drive, analytical ability and decision making, communication and interpersonal skills, team working abilities and skills, organisation, planning and prioritisation abilities, ability to innovate, mental and physical resilience, leadership ability, managing long term projects, time management, risk-taking, creativity, and being an agent of change. Engineer-entrepreneur dual roles impose a power of being a talented individual within an organisation, and are an important source for engineers to be actively involved with many innovation activities for organisational long-term successful entrepreneurial performance.

This present study has examined the influence of EO on ITS amongst Malaysian engineers. The findings of this study could be used to help organisations to encourage EO amongst engineers and control their movement to other employers. The talent retention model makes these findings less generalizable to other professional employees. However, this study realises a few potential limitations. Firstly, the sample size 
for data analysis and interpretation was small. Secondly, the response rate for the study was mainly recruited from limited states in Malaysia. Therefore, it is suggested to increase the number of participants from various nations and industrial businesses. Thirdly, this present study has used established items for measuring the EO of engineers within an organisation. There are still other specific but limited items for EO that can be used to measure individual EO. Hence, future research can identify the specific items for measuring the EO amongst key employees. It is also recommended that further research should explore, usefully, EO and talent retention amongst other professions, such as accountants, medical doctors, lawyers, lecturers, or architects. Further research is suggested to explore and combine the EO theory and other theories (e.g., social cognitive theory and social exchange theory) in predicting employee's behavioural intentions, job and career satisfaction. A greater focus on talent retention could produce interesting findings that account for more variables, such as teamwork, organisational citizenship behaviour, leader-member exchange, trust, and organisational support.

\section{References}

Abdull Rahman, R. H. (2012). Malaysian firms' role in retaining engineers.The Economic and Labour Relations Review, 23(4), 57-78.

Alavi, S. B., Moteabbed, \& S. Arasti, M. R. (2012).A qualitative investigation of career orientations of a sample of Iranian software engineers.Scientia Iranica, 19(3), 662-673.

Antoncic, J. A. \&Antoncic, B. (2011). Employee satisfaction, intrapreneurship and firm growth: A model. Industrial Management \& Data Systems, 111(4), 589-607.

Bigliardi, B., Petroni, A. \& A. I. Dormio, (2005).Organizational socialization, career aspirations and turnover intentions among design engineers.Leadership \& Organization Development Journal, 26(6), 424-441.

Bolton, D. L. \& Lane, M. D. (2012). Individual entrepreneurial orientation: development of a measurement instrument. Education and Training, 54(2/3), 219-233.

Campbell, R. I., Gluesing, J. \&Perelli, S. (2012). Mindfulness and product failure management: an engineering epistemology. International Journal of Quality \& Reliability Management, 29(6), 642-665.

Covin, J. G. Slevin, \& D. P. (1986). The development and testing of an organizational-level entrepreneurship scale in Ronstadt, R. et al. (Eds), Frontiers of Entrepreneurship Research, Babson College, Wellesley, MA, 628-39.

Crant, J. M. (2000). Proactive behaviour in Organizations.Journal of Management, 26(3), 435-462.

Elenurm, T. (2012).Entrepreneurial orientations of business students and entrepreneurs.Baltic Journal of Management, 7(2), 217-231.

Entebang, H., Harrison, R. T. \& Run, E. C. (2010).Entrepreneurial orientation of public enterprises in Malaysia.Business Strategy Series, Vol. 11, No. 2, pp. 75-77.

Festing, M. \&Scha“fer, L. (2014). Generational challenges to talent management: a framework for talent retention based on the psychological-contract perspective. Journal of World Business, 49, 262271.

Gelens, J., Dries, N., Hofmans, J. \&Pepermans, R. (2013). The role of perceived organizational justice in shaping the outcomes of talent management: a research agenda. Human Resource Management Review,23, 341-353.

George, C. Retaining professional workers: what makes them stay? Employee Relations, 37(1), 102-121.

Govaerts, N., Kyndt, E., Dochy, F. \&Baert, H. (2011). Influence of learning and working climate on the retention of talented employees. Journal of Workplace Learning, 23(1),35-55.

Grip, A. D. \& Smits, W. (2012). What affects lifelong learning of scientists and engineers? International Journal of Manpower, 33(5), 583-597.

Hair, J. F., Hult, G. T. M., Ringle, C. M., \&Sarsstedt, M. (2014).A primer on partial least squares structural equation modelling (PLS-SEM). California: SAGE Publication, Inc.

Igbaria, M. \& Siegel, S. R. (1992). An examination of the antecedents of turnoverpropensity of engineers: an integrated model. Journal of Engineering and Technology Management, 9, 101-126.

Igbaria, M., Kassicieh, S. K. \& Silver, M. (1999). Career orientations and career success among research, 
and development and engineering professionals.Journal of Engineering Technology Management16, 29-54.

Jia, J., Wang, G. \& Yu, X. Z. X. (2014).Exploring the relationship between entrepreneurial orientation and corporate performance.Nankai Business Review International, Vol. 5, No. 3, pp. 326-344.

Khalili, H., Nejadhussein, S. \&Fazel, A. (2013). The influence of entrepreneurial orientation on innovative performance.Journal of Knowledge-based Innovation in China, Vol. 5, No. 3, pp. 262-278.

Kharbanda, O. P. \&Stallworthy, E. A. (1990).Management for engineers.International Journal of Operations and Production Management, 10(6), 2-91.

Kollman, T., Christofor, J. \&Kuckertz, A. (2007).Explaining individual entrepreneurial orientation: conceptualisation of a cross-cultural research framework.International Journal of Entrepreneurship and Small Business, 4(3), 25-340.

Korte, R. \& Li, J. (2015).Exploring the organizational socialization of engineers in Taiwan.Journal of Chinese Human Resource Management, 6(1),33-51.

Lee, D. M. S. (1994). Social ties, task-related communication and first job performance of young engineers.Journal Engineering Technology Management, 11, 203-228.

Lewis, R. E. \& Heckman, R. J. (2006). Talent management: a critical review. Human Resource Management Review, 16, 139-154.

Lumpkin, G. T. \&Dess, G. G. (1996). Clarifying the entrepreneurial orientation construct and linking it to performance. Academy of Management Review, 21(1), 135-172.

Menzel, H. C., Aaltio, I. \&Ulijn, M. (2007). On the way to creativity: engineers as intrapreneurs in organizations. Technovation, 27, 732-743.

Oyedele, L. O. (2010). Sustaining architects' and engineers' motivation in design firms: an investigation of critical success factors. Engineering, Construction and Architectural Management, 17(2), 180196.

Tett, R. P. \& Meyer, J. P. (1993). Job satisfaction, organizational commitment, turnover intention, and turnover: Path analysis based on meta-analytic findings. Personnel Psychology, 46(2),342-346.

Tremblay, M., Wils, T. \&Proulx, C. (2002).Determinants of career path preferences among Canadian engineers.Journal of Engineering Technology Management, 19, 1-23.

Williamson, J. M., Lounsbury, J. W. Han, \& L. D. (2013). Key personality traits of engineers for innovation and technology development. Journal of Engineering Technology Management, 30, 157-168.

$\mathrm{Wu}$, J. (2009). Entrepreneurial orientation, entrepreneurial intent and new venture creation: test of a framework in a Chinese context. Unpublished Doctoral Thesis.Virginia Polytechnic Institute and State University.

Yang, C., Ma, Q. \& Hu, L. (2011). Job embeddedness: a new perspective to predict voluntary turnover. Nankai Business Review International, 2(4), 418-446.

Zhang, S. \& Bright, D. (2012).Talent definition and talent management recognition in Chinese privateowned enterprises.Journal of Chinese Entrepreneurship, 4(2), 143-163. 